\title{
The Ancient Origins of Medieval Fields: A Reassessment
}

Tom Williamson

This article questions the suggestions that have been made by a number of archaeologists and landscape historians concerning the Roman and prehistoric origins of large tracts of the medieval rural landscape in lowland England. It suggests that arguments for large-scale continuity of field systems, mainly based on the evidence of excavations and topographic analysis, are flawed because they fail to take fully into account the topographic contexts, and the practical functions, of field boundaries. When these matters are given due weight, much of the evidence cited in support of 'continuity' instead appears to suggest a significant degree of discontinuity, at least in terms of systems of land division, between Roman Britain and medieval England.

\section{INTRODUCTION}

A number of archaeologists and landscape historians have, over the years, argued that the essential layout of the rural landscape in some parts of England - the pattern of roads and field boundaries - originated, not in the Middle Ages or later, but in the prehistoric or Roman periods. Such arguments are based on two distinct but related approaches. The first approach is that of excavation. In a few cases, ditches underlying medieval boundaries have been dated to the Roman period by the character of the material in their fill; alternatively, medieval fields have been ascribed very early origins because their boundaries share a common orientation with nearby excavated features of prehistoric or Roman date. The second approach is that of topographic analysis. Boundary patterns in the modern landscape have been dated to the Roman period or earlier on the basis of horizontal stratigraphy — that is, they appear unconformable with Roman military roads, or linear earthworks - or because they share a common orientation (and thus display evidence of deliberate planning) over areas more extensive than medieval manors or parishes. For many researchers, the survival of Roman fields into the Middle Ages appears to suggest a significant measure of continuity, not only of land use and patterns of land allotment, but also of the systems of agrarian organisation underlying these. The longevity of field systems in lowland Britain therefore has wider implications for our understanding of the character of social, economic and cultural change in the post-Roman period.

This article suggests that such arguments for landscape 'continuity', certainly in their more extreme forms, are misleading. It is argued that such approaches are based on a neglect of 
both the topographic contexts, and the practical functions, of the field boundaries and boundary patterns examined. If anything, much of the evidence usually cited in support of 'continuity' can be interpreted in the opposite manner, suggesting in fact a significant degree of discontinuity, at least in terms of systems of land division, between Roman Britain and medieval England.

\section{ARGUMENTS FOR 'CONTINUITY'}

In the 1970s, Taylor and Fowler published a number of examples of open-field furlong boundaries which appeared to overlie earlier field ditches, for which a Roman origin was suggested (Fowler and Taylor 1978). Upex has likewise argued that some medieval furlongs in Northamptonshire evolved from Roman fields, partly based on the evidence of ditches containing Roman material found beneath the junctions of open-field furlongs 'which, within the width of the excavated trenches, appear to run parallel to the line of the headlands' (Upex 2002, 85). Similar claims have been made for the Roman or prehistoric origins of the furlong pattern around Shapwick in Somerset (Gerrard and Aston 2007, 53-55). Slightly different arguments for continuity have, however, recently been advanced by Rippon et al. (2015). They compared the orientations of a substantial sample of lost ditches, excavated and dated to the Roman period, with those of the field walls or hedges lying in the surrounding area, and argued that similarity of alignment constituted good evidence that Roman fields had morphed into medieval ones. They concluded that ' $64 \%$ of excavated Romano-British field systems in lowland England share a common orientation or alignment with medieval landscapes' (Rippon et al. 2015, 323): an astonishing figure which, if taken at face value, would suggest a very remarkable degree of 'continuity'.

Arguments for the prehistoric Romano-British origins of the medieval agrarian landscape have also drawn heavily on the evidence of topographic analysis. This approach was first developed in the nineteenth century but was given a new impetus in the 1970s and 1980s in the work of Rodwell and Drury (Rodwell 1978; Drury and Rodwell 1980). They noted that in some parts of Essex, a county in which the essential structure of the landscape had been established by the end of the medieval period, patterns of fields could be found, which, because their boundaries shared a common orientation across extensive areas, appeared to have been planned. Such cohesive landscapes could cover areas significantly larger than the vills or manors of the Middle Ages, implying that they had been laid out earlier, probably in 
the Roman period or the later Iron Age. Drury and Rodwell also drew attention to the fact that in a number of places in the same county, most notably at Little Waltham, early Roman military roads appeared to slice through the modern field pattern in a way analogous to a railway line or motorway, leaving awkward corners, in such a manner as to suggest that the fields were earlier, and thus of prehistoric date.

Subsequent research elsewhere in the country revealed many landscapes with similar attributes - large-scale cohesion and/or a non-comformable relationship with Roman military roads or early linear earthworks - which either survived as hedged fields or, more rarely, were documented on early maps as patterns of open-field furlongs. Examples were published from parts of Norfolk and Suffolk (Williamson 1987; 1998; Davison 1990; Hesse 1992); western and south-eastern Cambridgeshire (Oosthuizen 1998, 2003 and 2006; Harrison 2002); north-west Essex (Bassett 1982, 4-9); Lincolnshire (Bassett 1985); the dipslope of the Chiltern Hills in Hertfordshire (Williamson 2010); the London clay uplands in the south-east of that county (Hunn 2004; Bryant et al. 2005); and the Arrow valley of Shropshire, around Hergest and Lyonshall (White 2003, 37-47 and 73-75). Most of these landscapes displayed a distinctive 'co-axial' form — that is, they had a dominant 'grain' with axes running for much longer distances in one direction than another, so that they resembled in plan rather wavy and irregular brickwork (Illus. 1). In many cases a premedieval origin was apparently confirmed by the way that parish boundaries, largely established within a century or so of the Norman Conquest, join, leave, and rejoin these long axes in a manner which clearly indicates that they were already in existence (Rackham 1986, 19-20; Williamson 1986; Winchester 1990).

The term 'coaxial' was originally coined in the 1970s by Fleming to describe the extensive Bronze Age field systems which cover much of Dartmoor, and field patterns of this type form a common subsection of cohesive prehistoric and Romano-British landscapes known - as earthworks or as cropmarks — from many areas of Britain (Fleming 1978). The apparent resemblance of existing (or historically documented) field patterns, to these accepted prehistoric and Roman landscapes, led to the understandable conclusion that the former represented surviving, if much-altered, examples of the latter. This inference seemed to receive a measure of support from observations made by Fleming himself on the Dartmoor field systems, for on the fringes of the moor their main axes often appeared to continue onto lower, cultivated ground in the form of modern field boundaries (Fleming 1988, 27-30). 
Indeed, on the moor's eastern edge, around Kestor and in the Bittaford-Ivybridge area, 'most of the evidence' for the prehistoric systems came 'from the regular orientation of modern field boundaries' (Fleming 1988, 28).

Not all published examples of 'ancient planning' take a co-axial form. Some of the most striking have been described as 'planned grids' or 'semi-regular grids': rectilinear arrangements of fields and roads with axes that run equally strongly in two directions. These can cover relatively small areas, such as the examples published from Reed, or from the area around Aldenham, both in Hertfordshire; from Holme in north-west Norfolk; or from Tadlow on the Cambridgeshire/Bedfordshire border (Reid 1963; Hoskins 1967; Rackham 1986, 17677; Brown 1992). However, in some cases they extend over many tens of square kilometres, as in the Thurrock area of south Essex, or on the Dengie peninsula in the same county. Such examples of early grid planning are, it should be emphasized, rather different from the various schemes of 'centuriation' which have been suggested in Britain in the past, which like the ley lines and 'earth zodiacs' beloved of the archaeological 'fringe' - are reconstructed through the selection of disparate and discontinuous elements of the landscape, rather than through an analysis and interpretation of its overall form (Peterson 1990; Williamson and Bellamy 1983; Ferrar and Richardson 2003).

These topographic arguments for the ancient origins of the rural landscape have come in for some criticism, partly on grounds of inherent implausibility and partly on the grounds that there are problems with too simplistic an approach to dating field patterns by 'horizontal stratigraphy', that is, by their apparent relationships with Roman roads (Hinton 1997; Martin 1999; Martin and Satchell 2008, 214-16). In some cases, moreover, conventional archaeological approaches have produced dating evidence at variance with that suggested on the basis of topographic analysis. Excavations within the area of the Thurrock system, for example, have dated many of the features conforming to Rodwell's Roman 'grid' securely to the medieval period, and in a review of the evidence Tony Wilkinson concluded that 'a Roman date for the system must ... be viewed as unproven' (Wilkinson 1988, 126-28). Nevertheless, the idea that prehistoric or Roman field systems developed directly into medieval fields and furlongs, and that such survival indicates that the areas in question have, for the most part, remained in agricultural use across the intervening centuries, is still widely accepted, especially by landscape historians (Rippon et al. 2015, 313-28). Indeed, co-axial field patterns are recognized as a distinct landscape type, with early origins, in many of the 
county-based 'Historic Landscape Categorization' projects funded by English Heritage (e.g. Dyson-Bruce et al. 2006).

The Romano-British (or prehistoric) origins of medieval fields has thus been proposed on the basis of two distinct approaches: excavation and topographic analysis. In some studies, both approaches, or a hybrid approach, have been employed, most notably in Rippon et al.'s (2015) recent work. Nevertheless, the two kinds of argument are different and are best considered separately.

\section{ARE CO-AXIAL LANDSCAPES 'PLANNED FIELD SYSTEMS’?}

Underpinning many of the claims about 'relict landscapes' is the belief that where roads and boundaries share a similar orientation across extensive areas, this must be the consequence of deliberate planning. Indeed, in most published studies, no real attempt is made to assess whether other factors may have encouraged a degree of apparent regularity and cohesion. Such neglect is particularly noticeable in the case of 'co-axial' systems, for even a cursory examination reveals that their principal longitudinal elements are normally made up of roads or tracks which follow the dominant direction of slope, and thus run at right angles to a series of parallel environments. The south-east Cambridgeshire co-axials discussed by Harrison, for example, run for as much as ten kilometres from the edge of the peat Fens, up the chalk escarpment of the East Anglian Heights, and onto the boulder clay plateau above, which is still heavily wooded land (Harrison 2002, 40-41). Those in west Norfolk begin at coastal marshes, cross well-drained and moderately fertile land, and then run upwards onto areas of more acid soils which, in post-medieval times, were mainly occupied by heaths; yet, to judge from place-names, boasted at least some woodland in the early medieval period. Most coaxial field systems, however, begin on the edge of a valley floodplain, run up the welldrained slopes of a valley side, and then continue out onto wide drift-covered uplands. The 'Scole-Dickleburgh system' in south Norfolk, for example (Illus. 2), runs up and out of the valley of the river Waveney, here following a gently sinuous course, onto the extensive and relatively level boulder clay plateau to the north (Williamson 1998).

In this context, attention should be drawn to the fact that co-axial landscapes often occur in areas in which the arrangement of medieval parishes also takes a distinctive form, that is, in which they are laid out as a series of long, parallel strips. Notable cases of such coincidence 
can be found in north-west Norfolk, in south Norfolk, in south-central Essex, in south-east Hertfordshire and in south-east Cambridgeshire (Harrison 2002; Williamson 2010, 188-89; Hunter 2003, 31-35). As many writers have observed, 'strip' parishes generally developed where the principal soils types and natural resources are arranged as a series of parallel bands. The parishes lie at right angles to these, running, for example, from valley meadows, across a chalk escarpment, and up onto a drift-covered plateau (Rackham 1986, 20). Presumably the Anglo-Saxon estates from which these ecclesiastical units developed had likewise been so ordered, to ensure that they had access to a range of resources.

The fact that co-axial landscapes are often found in the same areas as 'strip' parishes does not, of course, mean that they are contemporary with them, or even with their secular predecessors. Harrison (2002) has shown that in south Cambridgeshire the parishes were unquestionably imposed upon an earlier co-axial arrangement, with their boundaries as usual following for a while, leaving, and then re-joining prominent linear elements. This recurrent association does, however, suggest that the two phenomena may have been a response to similar environmental influences or constraints. The parallel tracks - 'resource linkage routes', to adopt Harrison's term $(2005,159-60)$ — are best interpreted as a response to such banded topography, and were thus presumably used to move livestock from upland pastures to lowland fields and meadows, and back again. Indeed, other resources — wood, fodder, timber - would also have been regularly transported from higher ground to lower. Together, perhaps, with a small number of boundaries created to allocate portions of these resources to particular communities, they served to etch a 'grain' into the landscape which later, as more land was brought into cultivation and was enclosed as fields, became the dominant framework of the countryside.

In this process of in-filling, however, the tracks may often have become more fixed and defined: that is, the division of land into a mesh of enclosures may have created the tracks in the form in which we see them today, progressively narrowing and bounding wide and poorly defined droves and converting them into narrower hedged features. Either way, the importance of livestock movement in the genesis of such landscapes probably explains why their principal axes often pay little attention to minor features of the topography, such as shallow secondary valleys running at an oblique angle, even though their overall form is structured by the broader disposition of rivers and watersheds. Livestock are more easily 
moved in a direct line up moderate slopes, en route to distant grazing grounds, than wheeled vehicles.

The contrast between wooded uplands, cultivated lowlands, and floodplains or marshes was not in itself sufficient to generate co-axial landscapes. Such different environments needed to be ranged in near-parallel bands and the topography had to be relatively planar in character. The distance between neighbouring rivers needed, moreover, to be significant, otherwise, the pattern produced would not be extensive enough to be clear in the landscape, and thus come to the notice of modern researchers. Hence, the majority of examples are found where a river valley cuts through particularly extensive tracts of clay upland: in situations, that is, where the distance to the next valley is upwards of $c$. eight kilometres. Where the topography is more irregular and dissected, in contrast, strongly parallel patterns of roads fail to develop; and so it is that, as the terrain becomes more complex, co-axial landscapes will gradually 'fade' into areas of more irregular fields (Warner 1996, 48-51).

This interpretation of co-axial field patterns can be supported in other ways. Such landscapes sometimes include areas of ancient coppiced woodland. If these cover a relatively small area of ground, then they usually form one parcel within the pattern. However, if they are extensive they often appear to disrupt it, as if they had regenerated over an earlier system of fields. We might reasonable expect such woods to contain the earthworks of the lost section of the 'system', but they do not. Usually, as for example with Tindall Wood, Hedenham Wood, or Billingford Wood in south Norfolk, the interior or the wood is completely devoid of early earthworks, and evidently 'primary' rather than 'secondary' (sensu Peterken 1981) in character (Barnes and Williamson 2015, 48-54). More rarely, as in the case of the Wormley and Broxbourne woods in south-east Hertfordshire, a particularly extensive area of ancient woodland will contain one or more of the main longitudinal axes of the coaxial landscape, and very occasionally some lateral divisions, in earthwork form, but never a tight mesh of relict boundaries. The areas defined by banks and hollow ways within the woods are thus significantly larger than the fields conforming to the co-axial pattern lying outside them (Bryant et al. 2005, 14). These circumstances indicate that the framework of long axes, most of which originated as tracks, appeared first in the landscape. The subdivision of the spaces between them, into networks of small fields, came later. 
If this general explanation for the origins of co-axial field patterns is accepted, then it becomes clear that they cannot be dated in any simple way by the manner in which they appear to be 'slighted' by Roman military roads. The original relationship was not between the road, and a dense network of fields, but rather between the road and a widely spaced pattern of parallel droveways and boundaries. These could have been 'imposed on' the Roman road just as easily as the other way around. The difference in orientation is explained by difference of purpose; the lanes and boundaries linking and dividing the resources of a local environment, the Roman road taking a direct route from one place of military or civilian importance to another. It need thus carry no chronological implications (compare Illus 2 and $3)$.

\section{INTERPRETING 'SEMI-REGULAR GRIDS': DENGIE DISSECTED}

The 'semi-regular grids' identified at places like the Dengie peninsula in Essex, or in the Thurrock area immediately to the north of the Thames in the same county, are superficially more difficult to explain in terms of organic development, and they thus require slightly more discussion. Both of these examples are remarkable for their vast size: the 'system' at Dengie extends across an area of around one hundred square kilometres. A planned Roman origin for the road network on the peninsula was proposed by Miller Christy as early as 1926, but the landscape was subsequently brought to a wider prominence - together with that around Thurrock, which lies a few kilometres to the west - by Rodwell and Dury in the late 1970s and 1980s. Subsequently, it was discussed by Rackham in his History of the Countryside in 1986 (Christy 1921, 91-97; Drury and Rodwell 1980, 61-64; Rackham 1986, 159-61, 261).

Drury and Rodwell suggested a Roman origin for both the Dengie and Thurrock 'systems', in part because of their linear, regular character, but largely on the not unreasonable grounds that such exercises in planning and land allotment must imply the existence of a single authority. This suggested to them that the systems originated, at the very least, before the late Anglo-Saxon period, when Domesday depicts both areas as divided between numerous vills and lordships. Indeed, Drury and Rodwell speculated that both Dengie and Thurrock 'may have been Imperial estates' (Drury and Rodwell 1980, 64). In the case of Dengie, the presence of the Saxon Shore fort of Othona in the far north-east of the peninsula provided some support for such a suggestion. This dating was, however, revised by Rackham, who proposed instead a late prehistoric origin for both systems, which he described as 'semi- 
regular grids' (Rackham 1986, 159-61, 261). Rippon, in contrast, in a careful review of the evidence for Thurrock, suggested that the landscape was more complex than Rodwell had suggested, and that while some features might have survived from the Roman period, there was 'no evidence of an extensive planned landscape of this date'. He argued instead that the area had seen a 'major reorganization of the landscape, certainly between the fifth and the tenth centuries' - after the contraction in settlement and agriculture in the immediate postRoman period, but before the development of complex, splintered lordships in the late AngloSaxon period (Rippon 1991, 57-58). Rather than being associated with Roman Imperial estates, large-scale planning should be located in the period of the Middle Saxon 'multiple estates': large territorial units which were, at the time, a fashionable explanatory framework in landscape history, and still often invoked today (see Faith 2008 for a critique of the model). Yet, while the precise date of the Dengie and Thurrock field systems is thus debated, there has been a general agreement that both represent examples of large-scale landscape planning.

Dengie is particularly worthy of detailed examination, being the largest, the most continuous, and the most visually striking of the two 'systems'. However, like the co-axial landscapes discussed above, it looks different when considered within its topographic context, rather than as an abstract design 'imposed' on the topography. The first point to note is that Dengie is a peninsula, comprising London clay, gravels and brickearth, and characterized by relatively low but gently rolling relief. The peninsula is flanked by areas of marsh but these, crucially, are not evenly distributed around its margins. There are narrow strips of largely reclaimed marsh to north and south of the peninsula, against the estuaries of the Crouch and Blackwater; and much more extensive tracts of both embanked marsh and salt-marsh at its eastern end, projecting into the North Sea. The Essex coastal marshes had probably reached something close to their present limits by the third century $\mathrm{AD}$, but they were then largely inundated by marine transgression, before reforming during the early Anglo-Saxon period (Gascoyne and Medlycott 2014, 12). It is difficult to underestimate their economic importance in the past. Not only did they provide a wide range of natural resources, such as oysters, fish and salt - Romano-British 'red hills' (mounds of salt-making debris) are abundant at the western end of the Dengie peninsula, and numerous examples of Middle Anglo-Saxon fish traps are now known from the Essex coast (Strachan 1998). In addition, by late Anglo-Saxon times a large part of their value came from the extensive grazing they provided for sheep. Domesday shows that many inland manors in Essex had rights to use the 
coastal marshes, or possessed detached portions there; arrangements which Round and Darby both suggested had developed from more ancient systems, in which entire communities had regularly moved their flocks to the marshes on a seasonal basis; an argument further developed in recent years by Banham and Faith (Round 1903, 367-70; Darby 1971, 242-44; Banham and Faith 2014, 180). Outlying grazing farms, attached to remote manors, were often described as 'wicks': a common place-name on the Essex coast (Reaney 1935, 569 and 594). Places with names incorporating this element (and fields, probably the sites of lost farms) are clustered towards the eastern end of the Dengie peninsula, where the most extensive tracts of marsh are to be found (Essex Society for Archaeology and History 2003).

Having noted these characteristics of the local environment, we can turn to the layout of the 'field system' itself. Close examination reveals evidence for a significant degree of change over time. Many of the principal roads have evidently been narrowed and encroached upon in the remote past, sometimes by strips of woodland (as to the east of St Lawrence) and sometimes by houses, most dramatically at Latchingdon where the entire village plan appears to be the result of the infilling of wide droves or narrow linear commons (Illus. 4). Early maps confirm that some of the roads within the 'system' were wider even in the relatively recent past, and also that many of the field boundaries displayed a rather rougher conformity to the 'grid': examples of both can be seen, for example, on the 1717 survey of Snoreham Manor in Latchingdon, or the 1714 map of Keelings Farm in Dengie (ERO D/DRa P3; D/DP P18). New features added to the landscape in the course of the eighteenth and nineteenth centuries frequently replicated the general alignment of the 'grid', often in a more accentuated rectilinear form. The ruler-straight approach to Weymarks Farm in BradwellJuxta-Mare, for example, and its associated field boundaries, look like original elements but they did not exist when the property was mapped in 1714 (ERO T/M 301). This map, and more dramatically the Keelings House survey of 1714 and a map of Ammer House Farm in Latchingdon of 1696, also shows more roads and tracks than existed within the areas in question by the late nineteenth century (ERO D/DHt P2). There appears to have been a tendency for many of the private roadways forming elements of the 'grid' to either disappear altogether, or to be converted to field boundaries, while those with the status of public highways survived.

Other signs of a long and complex history are evident. Some of the fields have boundaries with the characteristically sinuous form, indicative of early enclosure from open-field arable, 
and limited areas of open-field, intermixed with enclosed land. Such fields certainly existed in this part of Essex in the Middle Ages, being referred to at Lawling in 1309, for example (Roden 1973, 340). This is evidently an old landscape and, like all old landscapes, it has undergone numerous piecemeal alterations over time.

In terms of overall layout, the most important point to emphasize is that there is much less coherence to the pattern of fields and lanes than the description 'planned landscape' might suggest (Illus. 5). The fields are mostly rectangular in shape but their orientation shifts significantly from place to place. Their boundaries are laid out at right angles to, or parallel with, a number of relatively straight alignments of road, the most striking of which is perhaps that which runs for four kilometres along the northern boundary of Asheldham and Dengie parishes. However, rather than sharing a common orientation, the main axes seem to fan out towards the east, broadly replicating the shape of the peninsula itself, which widens significantly from west to east. This aspect becomes more apparent if we consider only those elements of the landscape which appear prominent and potentially early; not the boundaries of every individual field, that is, but the major features, which we might define as those extending in length for half a kilometre or more. Some of these axes are formed by roads, others by field boundaries, but many are both. In other words, the axes change character along their length. An east-west road will thus be 'deflected', as it were, by a north-south axis, following it for a short distance before returning to an east-west orientation (Illus. 6). The most likely interpretation of this phenomenon is that most, or all, the main elements originally served as trackways, but many were later largely converted into boundaries at some time in the past, often perhaps as the landscape became more intensively used and more minutely subdivided in the Middle Ages, but sometimes, as noted earlier, during relatively recent times.

When the east-west axes are mapped separately (Illus. 7), it immediately becomes apparent that they occur throughout the peninsula, begin some way to its west, and fan out as they move through it, as if to access the extensive marshes at its eastern end. And this, of course, is a strong indication of their precise function; something that becomes particularly clear when their relationship to surviving wick names is considered (Illus. 8). The north-south axes, in contrast, have a more localized and patchy distribution (Illus. 9). They tend to be focused on smaller areas of marshland; run for shorter distances; and, perhaps significantly, are broadly associated with the sites of parish churches, which themselves probably mark the 
locations of the principal Middle Anglo-Saxon settlements in the district. These axes clearly represent localized 'resource-linkage' routes, forming a series of miniature co-axial landscapes. In some cases, these may have connected marshes at one end, with residual areas of wood-pasture on the higher ground at the other. Although the peninsula had already lost most of its woodland by the time of Domesday, it does contain a number of ancient woods, some of which are included on the Ancient Woodland Inventory but others omitted, in part because of their size (below the official 2-hectare cut-off point). There are also a number of place-names relating to woodland or its clearance, including Purleigh, Reddings Farm in Tillingham, and Hockley in Bradwell.

The great planned 'grid' of the Dengie peninsula is thus an illusion. It is generated by the intersection of localized north-south co-axial landscapes with a more extensive, east-west arrangement of roughly parallel routeways, together with a marked but understandable tendency for later field boundaries to be laid off these principal elements at rights angles. This does not mean that the landscape completely lacks planned elements. But its overall layout is the consequence of organic development, and apparently in the post-Roman centuries. While it is true that some of the cropmarks recorded on Dengie conform to the orientation of the surrounding field boundaries, most of these can be identified with features removed since the Ordnance Survey First Edition 6" map was surveyed in 1877, or since the tithe maps were drawn up around 1840. The majority of cropmarks of tracks and field boundaries are aligned at a significantly different angle to the surrounding grid, such as the rectangular enclosures and linear features destroyed by quarrying to the north-west of Asheldham church, which were shown by excavation to be largely of Roman date (TL 977018: Essex HER 12183).

Space does not permit a similar discussion of the other examples of 'planned grids' proposed over the years by historians and archaeologists, whether extensive - like that in the Thurrock area a few kilometres to the west - or more localized in character. It can be suggested, however, that these also appear to have post-Roman origins, and to have developed organically, through the intersection, or overlapping, of bundles of trackways ranged at right angles: one set usually of a long-distance character, the other generated by more localized patterns of exploitation. 
Some readers may be sceptical of these 'organic' explanations for apparently regular landscapes, whether of grid or of co-axial form. But those whose believe that these were, indeed, created by large-scale planning need to explain more clearly why this was undertaken and what it was supposed to achieve. When attempts have been made to do this in the past they have often seemed vague and half-hearted: Rodwell for example suggested, in the case of the examples at Thurrock and Dengie, that 'presumably it was felt that the productive capacity of London clay and gravel lands could be improved substantially by the application of new methods and working arrangements' (Drury and Rodwell 1980, 64). It is also worth noting, perhaps, that even the Dartmoor 'reeves', once universally accepted as the product of large scale prehistoric planning, have themselves been reinterpreted more recently as the consequence of gradual, accretive, development (Johnson 2005).

\section{EVIDENCE FROM EXCAVATION}

The argument so far does not deny that some elements of these distinctive landscapes whether 'planned grids' or co-axial layouts — might have early origins. Their essential characteristics suggest that they developed in circumstances of low population density, and within large agrarian territories in which restricted areas of arable land existed beside extensive tracts of woodland and grazing. Such conditions were probably present in many areas in the early Anglo-Saxon period but not to the same extent, perhaps, in the populous Romano-British countryside, when settlement and arable land use appears to have been extensive on most soils (Taylor 2007, 23-53). Yet extensive forms of exploitation of this kind must have existed in still earlier periods, and might have engendered some landscape elements which survived through Roman and into Anglo-Saxon times, and thus into the present. Some archaeological evidence certainly hints at this possibility.

In north-west Norfolk, for example, excavations in 1998 by Sarah Percival at Burnham Sutton produced apparent evidence for the survival and continued development of sections of a late prehistoric co-axial field system through to the late Anglo-Saxon period, and for the subsequent insertion within it of bundles of open-field strips (Perciful and Williamson 2003). An excavation within Cheshunt Park, more or less in the centre of the area occupied by the coaxial system around Broxbourne and Wormley in south-east Hertfordshire, revealed ditches conforming in orientation to the surrounding landscape which contained first and 
second-century pottery, and which had apparently been filled in during the construction or expansion of a small Roman settlement (Bryant et al. 2005, 13-14; Ely and Edwards 2003). On the other side of Hertfordshire, just to the north of Watford, excavations carried out at The Grove in 2000 revealed ditches representing lost elements of the local co-axial field pattern, which had been removed when a landscape park was laid out in the eighteenth century, several of which contained sherds of Iron Age pottery in their fill (Le Quesne et al. 2001).

These examples suggest that particular landscapes elements - individual boundaries and tracks - might continue in use from the prehistoric and Roman periods into the Middle Ages, but this is not quite the same as the survival of entire field systems. A consideration of such evidence, moreover, bring us to the more general question of how reliably modern boundaries patterns can be dated by excavation, and in particular by the character of the material excavated from nearby features with which they share a common orientation. The first point to emphasize is that it is notoriously hard to date existing field ditches because, since first created, they have been in a constant state of maintenance and modification. In the kinds of lowland terrain where evidence of 'continuity' has generally been found, field ditches, usually accompanied by banks and hedges, did not merely serve as stock-proof barriers or as property boundaries. They also usually fulfilled an important drainage function (Harvey 1980, 70-71). They formed 'a complex network, linking together features of the human landscape, such as moats and common edges, and natural watercourses' (Hall 1999, 38-39). They were, accordingly, thoroughly dug out when the associated hedge was coppiced, or plashed (that is, cut back and the main stems woven through upright stakes), usually at intervals of ten or twelve years. Such maintenance was necessary because the ditches became filled with material washed down from the adjacent bank, with silt brought down from higher up the system, and with soil brought in from the surface of the adjacent field by ploughing, harrowing and other agricultural operations. The latter might contain stray sherds derived from nearby occupation sites, or from manuring scatters, making dating problematic. As Rippon has noted: 'The excavation of individual field boundaries is unlikely to provide good dating evidence due to their mobility and disturbance through continual recutting' (Rippon 1991, 51).

All this is true not only of existing boundaries, of course, but also of ones which have been completely abandoned in the past and either deliberately filled in or gradually obliterated by silting. In consequence, an excavated ditch sharing the same alignment as an extant field 
boundary a few metres away might well have been first cut several hundred years before it, but not necessarily as early as the date suggested by the prehistoric or Roman material found in its fill. The paucity of Anglo-Saxon pottery found on settlement sites or as manuring scatters, in comparison with the large quantities of Roman sherds, should be remembered here. The span of time which has passed since the digging of a ditch in the thirteenth century is much the same as that which had elapsed between that event, and the end of Roman rule in Britain. Boundary systems must have undergone numerous changes in the course of the Anglo-Saxon period, and many of the excavated boundaries found running parallel to or beneath medieval hedges or headlands are as likely to be of post-Roman as of Roman date.

There are, moreover, a number of reasons, besides 'continuity', why a modern field boundary and a nearby one of prehistoric or Roman date might share a similar orientation. One is simple coincidence; another is the operation of similar agricultural or topographic influences in quite separate periods of time. Ditched boundaries were often aligned at approximate right angles to the main direction of slope in order to improve drainage (as were the open-field strips from which many enclosed fields directly developed in late medieval and early post medieval England, as common arable was enclosed in a gradual, piecemeal fashion) (Hall 1999, 33; Yelling 1977, 11-29). In addition, it was generally easier to plough along, or at right angles to, the main direction of slope, than diagonally across it, especially with a heavy plough drawn by a number of animals, and where the ground sloped steeply. Unease about how effectively extant boundaries can be dated by the similarity of their alignment with excavated features is increased by the fact that 'similarity' is a flexible concept. The excavations carried out in 2001 near Leen Farm in Pembridge, within the co-axial field system of the Arrow valley in Shropshire, revealed a number of 'lost' boundaries on a similar alignment to the existing hedges which contained large quantities of Iron Age and RomanoBritish pottery. The excavators tentatively suggested that 'perhaps the organization of the field pattern today is derived from the organization of the landscape nearly 2000 years ago' (White 2003, 45). Yet an examination of the published plan shows that the orientation of the 'dated' features, while close to, is nevertheless discernibly different from that of the upstanding boundaries nearby.

The uncertain dating of lost ditches through excavation, plus the fact that a range of practical factors might engender similarity of orientation in different periods, means that we need to be 
cautious about how, precisely, we interpret the fact that ' $64 \%$ of excavated Romano-British field systems in lowland England share a common orientation or alignment with medieval landscapes' (Rippon et al. 2015, 323). But even where prehistoric or Roman systems of land division have influenced, or determined, the layout of medieval boundaries or boundary patterns, this does not necessarily imply the "continuous agricultural usage of the areas concerned' proposed by Drury and Rodwell (Drury and Rodwell 1980, 59). Long-abandoned earthworks may have been reused as boundaries, as Hunter argued was the case with some of the Essex 'systems'. When land was recolonized after a phase of abandonment, he suggested, it was easier to dig out an existing silted ditch, surviving in earthwork form, than it was to create an entirely new one from scratch (Hunter 2003, 35).

\section{EVIDENCE FROM AERIAL PHOTOGRAPHY}

The evidence from excavations supposedly demonstrating large scale 'continuity' of field patterns is, we might also note, somewhat at variance with that forthcoming from aerial photography. Cropmarks of prehistoric and Roman date, except once again where there are obvious topographic imperatives, frequently display significantly different alignments to the medieval field or furlong boundaries around them. A recent AHRC-funded project, which involved the reconstruction of the entire layout of medieval open fields in the county of Northamptonshire, makes the point well (the data is freely available from the Archaeological Data Service) (Williamson et al.2011; Williamson et al. 2013). The reconstructed furlong patterns, and the cropmarks plotted as part of the National Mapping programme, usually lie at quite different angles. This is particularly striking given that prehistoric and Roman crop marks are concentrated on precisely the kinds of light, freely-draining soils on which, as many have suggested, continuity of settlement and land use between the Roman and medieval periods was most marked. Of course, the crop-mark landscapes are mostly undated, and in some cases represent collections of features which were already old, redundant and levelled by the end of the Roman period. But the rarity of shared alignment in this county is nevertheless remarkable. Less than $10 \%$, and probably less than $5 \%$, of prehistoric and Roman cropmarks of enclosures, field boundaries and trackways share, to within 5 degrees, the orientation of the surrounding open-field strips. The difference in orientation is particularly clear where cropmarks cover large and continuous areas of ground, as with the extensive prehistoric and Roman complexes at Brampton and Harlestone (Illus. 10). 
The minority of cases where crop-marks and furlongs lie on similar alignments are mainly found in areas of poorly draining boulder clay, especially in Kingsthorpe, Hemington, Barnwell, and Lutton, where there is very little evidence for settlement in the fifth and sixth centuries AD. Whether this pattern suggests that, on poorly draining soils, there was a greater likelihood for boundaries in all periods to be aligned in a similar manner, best suited for the removal of water; or whether redundant earthworks beneath secondary woodland influenced the layout of fields when cultivation re-expanded onto marginal land in late Saxon or medieval times; remains unclear (Williamson et al. 2013, 50-53).

Once again, this argument must be measured and we should not deny that some prehistoric or Roman boundaries and trackways may have continued in use into the medieval period. It would be remarkable indeed if the changes of the fifth and sixth centuries AD had completely wiped the slate of the landscape clean across lowland England. However, the suggestions recently made by some archaeologists and historians, that many or even most Roman fields remained intact and functioning into the early Middle Ages, seems difficult to sustain on present evidence (see e.g. Oosthuizen 2016, 182-85).

\section{CONCLUSION}

This discussion brings us to what is, perhaps, the real lesson that we should draw from the evidence provided by the kinds of topographic approaches to the historic landscape with which this paper has been particularly concerned. Much has been made of the way in which Roman military roads appear, in certain districts, to 'slight' the field patterns either extant today, or shown on the earliest available maps, suggesting their prehistoric or early Roman origins. In fact, what is striking is the rarity of this phenomenon. In old-enclosed areas of England (that is, in Rackham's (4-7) 'ancient countryside') — where the field pattern has developed organically, incorporates numerous medieval elements, and is not largely the consequence of parliamentary enclosure or other forms of post-medieval re-organization - it is possible to follow Roman roads for mile after mile, without finding the slightest hint that they have been imposed upon an earlier network of fields and lanes. Only where strong topographic imperatives exist - such as the kinds of banded arrangement of resources discussed above - does a clear dissonance in orientation, between road and surrounding landscape, become apparent. The same is true where Roman roads are examined on preenclosure maps of open-field districts: furlongs are almost always, except in the 
circumstances just noted, laid off the road at approximate right angles. In its entire course through Northamptonshire, a distance of nearly forty kilometres, Watling Street runs conformably with the surrounding medieval furlongs, as reconstructed through cartographic and archaeological evidence (Illus. 11: Williamson et al. 2011).

It might, of course, be argued that this circumstance merely reflects the fact that the basic structure of the landscape in most areas is of Roman date-post-dating the Roman road, although not perhaps by very long — rather than having prehistoric origins. However, we also need to consider the many cases in which Roman military roads have themselves completely disappeared for long stretches, leaving no trace of their existence even as field boundaries. It is very hard to believe that the fields in these same areas have somehow survived, en masse, from the Roman period, while the road - which must have formed an integral part of the boundary pattern - has so completely vanished. A Roman road leaves the south-western or Silchester Gate of the town of Verulamium near St Albans in Hertfordshire, heading for the Gade valley some seven kilometres to the south-west (Niblett and Thompson 2005, 57). There is no obvious sign of it crossing the remarkable co-axial field patterns which dominate the landscape of the Chiltern dipslope to the south-west of the town. It would be strange indeed if these somehow survived relatively intact from the remote past, while the road itself had disappeared. Oosthuizen has recently argued for large-scale continuity from the Roman period, into the Middle Ages, not only of field systems but of the systems of property rights with which these were associated. She has even gone so far as to suggest that open-field agriculture itself may have had prehistoric or Roman origins (Oosthuizen 2016). If, however, systems of land allotment really had displayed this kind of stability it should be far more obvious in the layout of the medieval and modern landscape.

The evidence of pollen analysis may indicate the maintenance of a largely open environment — or at least, only limited increases in the extent of existing woodland — during the immediate post-Roman period. Conversely, this data also indicates a marked reduction in the extent of arable land use (Murphy 1994, 37; Dark 2000; Foard 2001). As Faith has argued, the economy of the fifth and sixth centuries AD was largely geared to livestock husbandry (Faith 2009). This in turn must be associated with the fact that, to judge from the numbers and distribution of fifth and sixth-century settlements recovered by field surveys, the population declined significantly in the late or immediate post-Roman periods. The 'relict landscapes' discussed here, far from indicating large-scale Roman or prehistoric planning 
followed by solid post-Roman continuity, are perhaps best viewed in this context. Their character implies an economy based on limited areas of arable land and the exploitation of wide tracts of woodland pastures within extensive social territories; while their undeviating axes suggests that they developed in environments largely unobstructed by other functioning man-made barriers or boundaries. The very existence of such field patterns thus suggests that the roots of the medieval countryside lay in a largely pastoral Anglo-Saxon landscape, whose inhabitants made only limited use of the mesh of enclosures which they had inherited from earlier, more crowded times.

\section{ACKNOWLEDGEMENTS}

I would like to thank Adrienne Compton, Sarah Harrison and Rob Liddiard for advice, ideas and suggestions; the staff of the Essex Record Office, Chelmsford for assistance with maps and archives; and the referees who provided important and useful comments on the initial version of this article.

\section{BIBLIOGRAPHY}

PRIMARY SOURCES

Essex Record Office (ERO) D/DRa P3: survey of Snoreham Manor in Latchingdon, 1717

ERO D/DP P18: 1714 map of Keelings Farm, Dengie parish, 1714

ERO T/M 301: survey of Weymarks Farm in Bradwell-Juxta-Mare, 1714

ERO D/DHt P2: survey of a farm in Latchingdon, 1696

\section{SECONDARY SOURCES}

Banham, D. And Faith, R. 2014. Anglo-Saxon Farms and Farming, Oxford: Oxford University Press 
BARNES, G. AND WILLIAMSON, T. 2015. Rethinking Ancient Woodland, Hatfield: University of Hertfordshire Press

BASSETT, S. R. 1982. Saffron Walden: Excavations and Research (1972-1980), London: Counc. Brit. Archaeol.Res. Rep., 45, London: Council for British Archaeology

BASSETT, S. R. 1985. Beyond the edge of excavation: the topographical context of Goltho, in H. Mayr-Harting and R. I. Moore (eds) Studies in Medieval History Presented to R. H. C Davis, 21-39, London: Hambledon

BROWN, W. N. 1992. A Roman settlement in Aldenham?', Hertfordshire's Past, 33, 34-7.

BRYANT, S., PERRY, B. AND WILLIAMSON, T. 2005. A 'relict landscape' in south-east Hertfordshire: archaeological and topographic Investigations in the Wormley area, Landscape History 27, 5-15.

CHRISTY, M. 1921. On Roman roads in Essex, Trans. Essex Archaeol.l Soc., 15, 190-229

DARBY, H. C. 1971. The Domesday Geography of Eastern England, Cambridge: Cambridge University Press

DARK, P. 2000. The Environment of Britain in the First Millennium AD, London: Duckworth

DAVISON, A. 1990. The Evolution of Settlement in Three Parishes in South East Norfolk, East Anglian Archaeol. Rep., 49, East Dereham:Norfolk County Council.

DRURY, P. AND RODWELL, W. 1980. Settlement in the later Iron Age and Roman periods, in D. G. Buckley (ed.) The Archaeology of Essex to AD 1500, Counc. Brit. Archaeol. Res. Rep., 34, 59-75, London: Council for British Archaeology

DYSON-BRUCE, L., BRYANT, S. AND THOMPSON, I. 2006. Historic Landscape Character: County Report for Hertfordshire, Hertford: Hertfordshire County Council. 
ELY, K. D. AND EDWARDS, K. 2003. Cheshunt Park, Hertfordshire: an Archaeological Evaluation by the Time Team, Unpublished Report, Bristol

ESSEX SOCIETY FOR ARCHAEOLOGY AND HISTORY. 2003. Essex Place-names Project: www.essex.ac.uk/history/esah/essexplacenames.

FAITH, R. 2008. Forms of dominance in the early medieval landscape, Medieval Settlement Res. Group Annual Rep., 23, 9-13

FAITH, R. 2009. Forms and relations of production in early medieval England, J. Agrarian Change, 9, 23-41

FERRAR, M. J. AND RICHARDSON, A. 2003. The Roman Survey of Britain, Oxford: Brit. Archaeol. Rep. Brit. Series, 359

FLEMING, A. 1978. The prehistoric landscape of Dartmoor: Part 1, south Dartmoor, Proc. Prehist. Soc., 44, 97-123

FLEMING, A. 1988. The Dartmoor Reeves, London: Batsford

FOARD, G. 2001. Medieval woodland, agriculture and industry in Rockingham Forest, Northamptonshire, Medieval Archaeol., 45, 41-95

FOWLER, P. AND TAYLOR, C. 1978. Roman fields into medieval furlongs, in H. C. Bowen and P. J. Fowler (eds) Early Land Allotment, 159-62, Oxford: Brit. Archaeol. Rep. Brit Ser. 48.

GASCOYNE, A. and MEDLYCOTT, M. 2014. The Essex Grazing Marsh Project, Chelmsford: Essex County Council

GERRARD, C. AND ASTON, M. 2007 Interpreting the English Village: Landscape and Community at Shapwick, Somerset, Oxford: Windgather. 
HALL, D. 1999. The drainage of arable land in medieval England, in H. Cook and T. Williamson (eds) Water Management in the English Landscape: Field, Marsh and Meadow, Edinburgh: Edinburgh University Press

HARRISON, S. 2002. Open fields and earlier landscapes: six parishes in south-east Cambridgeshire, Landscapes, 3, 35-54

HARRISON, S. 2005. A History of Evolution and Interaction: Man, Roads and the Landscape to 1850, unpublished PhD thesis, University of East Anglia

HARVEY, N. 1980. The Industrial Archaeology of Farming in England and Wales, London: Batsford

HESSE, M. 1992. Fields, tracks and boundaries in the Creakes, south Norfolk, Norfolk Archaeol., 41, 305-24

HINTON, D. 1997. The 'Scole-Dickleburgh Field System' examined, Landscape Hist., 19, $5-13$

HOSKINS, W. G. 1967. Fieldwork in Local History, London: Faber and Faber

HUNN, J. R. 2004. Tytenhanger: Excavation and Survey in the Parish of Ridge, Oxford: Brit. Archaeol. Rep. Brit. Ser. 381

HUNTER, J. 2003. Field Systems in Essex, Colchester: Essex Society for Archaeology and History

JOHNSON, R. 2005. Pattern without a plan: rethinking the Bronze Age coaxial field systems of Dartmoor, south-west England, Oxford J.Archaeol., 24(1), 1-21

LE QUESNE, C., CAPON, L. AND STEVENS, T. 2001. Post-excavation assessment of The Grove Estate, Watford, unpublished report, Hertford: Hertfordshire County Council Environment Department 
MARTIN, E. 1999. Suffolk in the Iron Age, in J. Davies and T. Williamson (eds) Land of the Iceni: the Iron Age in Northern East Anglia, 44-99, Norwich: Centre of East Anglian Studies

MARTIN, E. AND SATCHELL, M. 2008. Wheare Most Enclosures Be: East Anglian Fields - History, Morphology and Management, East Anglian Archaeol. Rep., 124, Ipswich: Essex County Council

MURPHY, P. 1994. The Anglo-Saxon landscape and rural economy: some results from sites in East Anglia and Essex, in J. Rackham (ed.) Environment and Economy in Anglo-Saxon England, Counc. Brit. Archaeol. Res. Rep., 89, 25-37, York: Council for British Archaeology

NIBLETT, R. and THOMPSON, I. 2005. Alban's Buried Towns: an assessment of St Albans' Archaeology up to AD 1600, Oxford: Oxbow Books

OOSTHUIZEN, S. 1998. Prehistoric fields into medieval furlongs? Evidence from Caxton, south Cambridgeshire, Proc. Cambridgeshire Antiq. Soc., 86, 145-52

OOSTHUIZEN, S. 2003. The roots of common fields: linking prehistoric and medieval field systems in west Cambridgeshire, Landscapes, 4, 145-52

OOSTHUIZEN, S. 2006. Landscapes Decoded: the Origins and Development of Cambridgeshire's Medieval Fields, Hatfield: University of Hertfordshire Press

OOSTHUIZEN, S. 2016. Recognizing and moving on from a failed paradigm: the case of agricultural landscapes in Anglo-Saxon England c. AD 400-800, J. Archaeol. Res., 24, 179227

PERCIFUL, S. and WILLIAMSON, T. 2003. Early fields and medieval furlongs: excavations at Creake Road, Burnham Sutton, Norfolk, Landscapes, 6, 1-17

PETERKEN, G. 1981. Woodland Conservation and Management, Cambridge: Cambridge University Press 
PETERSON, J. W. M. 1990. Roman cadastres in Britain: II - Eastern A: signs of a large system in the northern English Home Counties, Dialogues d'Histoire Ancienne 16 (2), 233272.

RACKHAM, O. 1986. The History of the Countryside, London: Dent

REANEY, P. H. 1935. The Place-Names of Essex, Cambridge: Cambridge University Press

REID, R. H. 1963. Reed: a topographical problem, Hertfordshire Past and Present, 3, 19-24

RIPPON, S. 1991. Early planned landscapes in south-east Essex, Essex Archaeol. Hist., 22, $46-60$

RIPPON, S., SMART, C. and PEARS, B. 2015. The Fields of Britannia, Oxford: Oxford University Press

RODEN, D. 1973. Field systems of the Chiltern Hills and their environs, in A. R. H. Baker and R. A. Butlin (eds) Studies of Field Systems in the British Isles, 325-76, Cambridge: Cambridge University Press.

RODWELL, W. 1978. Relict landscapes in Essex, in H. C. Bowen and P. J. Fowler (eds) Early Land Allotment, 89-98, London: British Archaeological Reports,.

ROUND, H. 1903. Domesday, in H. A. Doubleday (ed.) The Victoria History of the County of Essex, Volume 1, 427-578, London: Constable,

UPEX, S. 2002. Landscape continuity and the fossilization of Roman fields, Archaeol. J., 159, 77-108

STRACHAN, D. 1998. Inter-tidal stationary fishing structures in Essex: some C14 dates, Essex Archaeol. Hist., 29 274-84

TAYLOR, J. 2007. An Atlas of Roman Rural Settlement in Britain, York: Council for British Archaeology Res. Rept. 151. 
WARNER, P. 1996. The Origins of Suffolk, Manchester: Manchester University Press

WHITE, P. 2003.The Arrow Valley, Herefordshire: Archaeology, Landscape Change and Conservation, Hereford: Herefordshire Archaeology Service

WILKINSON, T. J. 1988. Archaeology and Environment in South Essex, East Anglian Archaeol. Rep.,42, Chelmsford: Essex County Council

WILLIAMSON, T. 1986. Parish boundaries and early fields; continuity and discontinuity, J.Hist. Geogr., 2(3), 241-48

WILLIAMSON, T. 1987. Early co-axial field systems on the East Anglian boulder clays, Proc. Prehist. Soc., 53, 419-31

WILLIAMSON, T. 1998. The 'Scole-Dickleburgh Field System' revisited, Landscape Hist., 20, 19-28

WILLIAMSON, T. 2010. The Origins of Hertfordshire, Hatfield: University of Hertfordshire Press

WILLIAMSON, T. and BELLAMY, L. 1983. Ley Lines in Question, London: World's Work

WILLIAMSON, LIDDIARD, R., PARTIDA, T., FOARD, G, HALL, D. AND McCLAIN, A. 'A GIS aided study of agriculture and landscape in Midland England' (http://archaeologydataservice.ac.uk/archives/view/midlandgis_ahrc_2010)

WILLIAMSON, T., LIDDIARD, R. AND PARTIDA, T. 2013. Champion: the Making and Unmaking of the English Midland Landscape, Liverpool: Liverpool University Press

WINCHESTER, A. 1990. Discovering Parish Boundaries, Princes Risborough: Shire.

YELLING, J.A. 1977. Common Field and Enclosure in England, 1450-1850, London: Macmillan. 


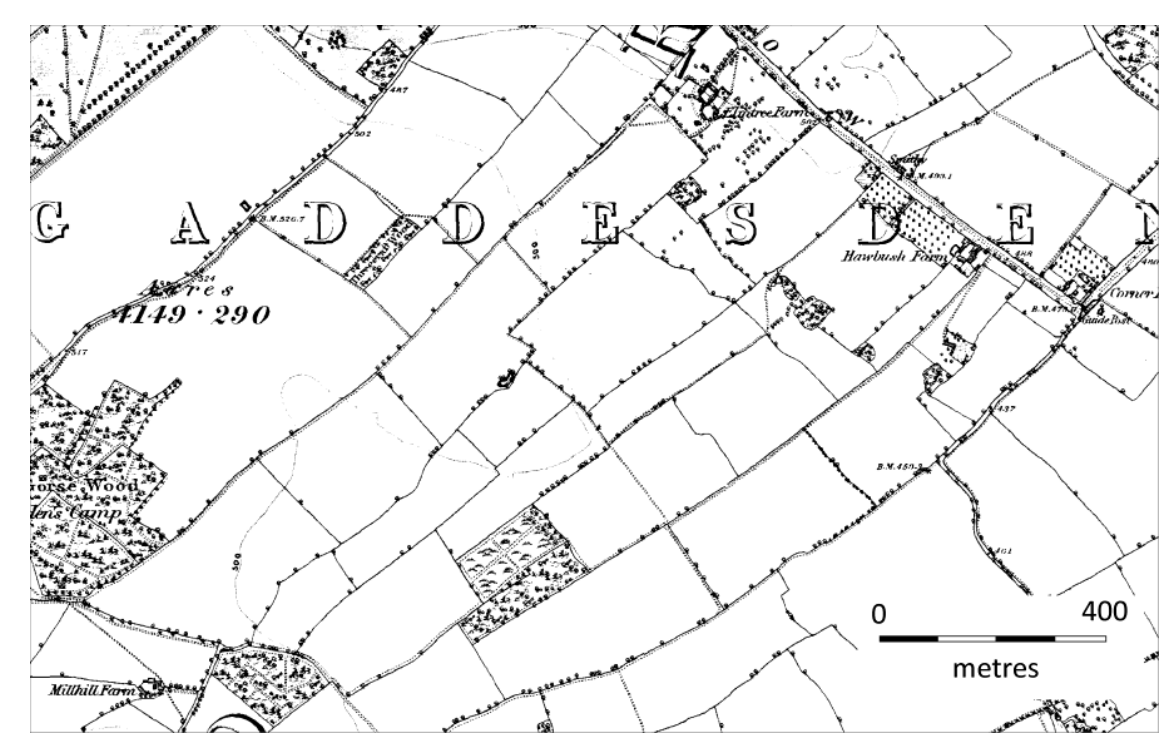

1. Typical co-axial field pattern, Great Gaddesden, west Hertfordshire, as shown on the Ordnance Survey 1: 10,560 map of 1877.

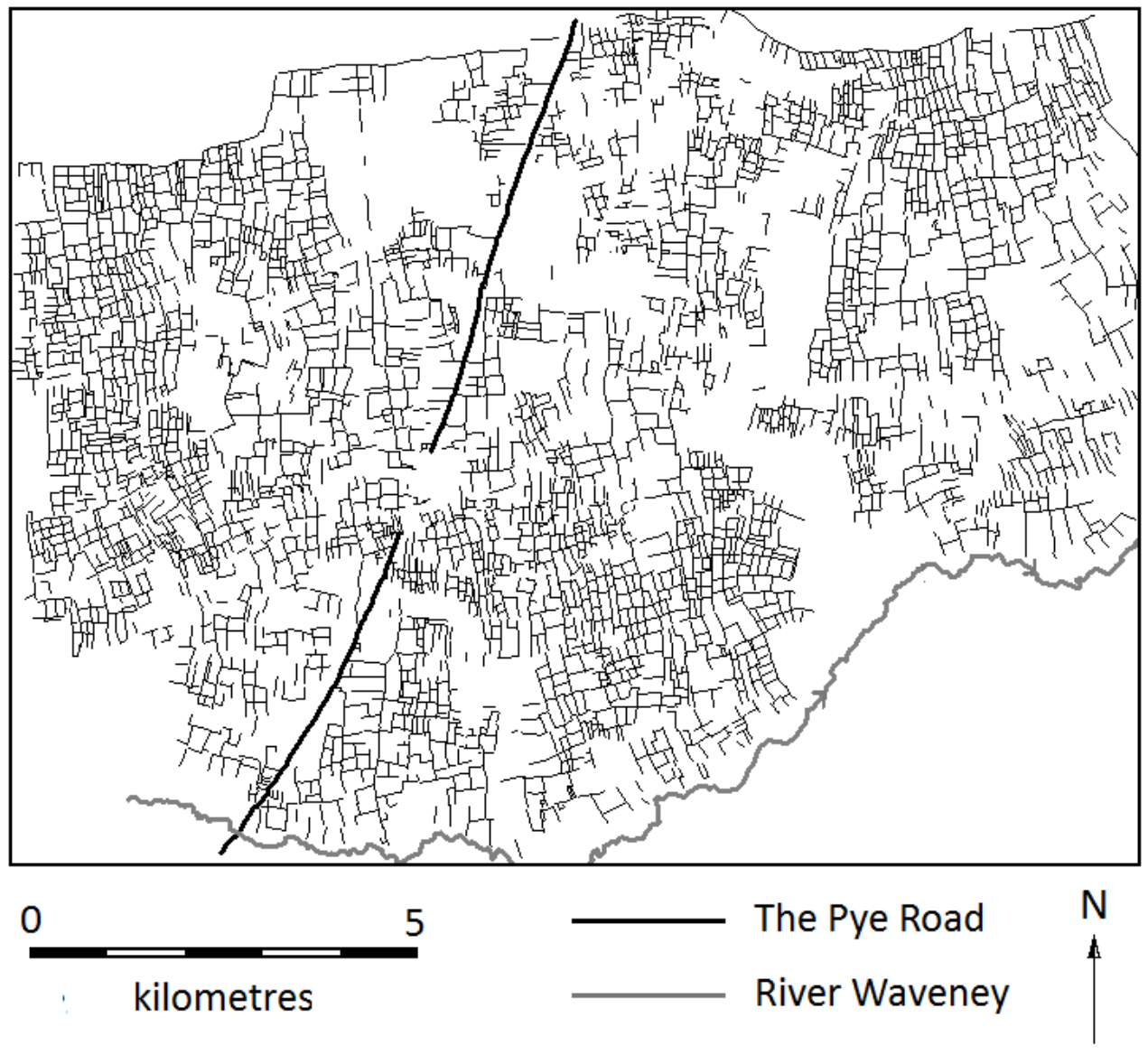

2. The 'Scole-Dickleburgh field system' in south Norfolk: a co-axial landscape apparently 'slighted' by the Roman Pye Road. Based on the earliest known maps for the various parishes in the area, with the pattern enhanced by selective removal (see Williamson 1987). 

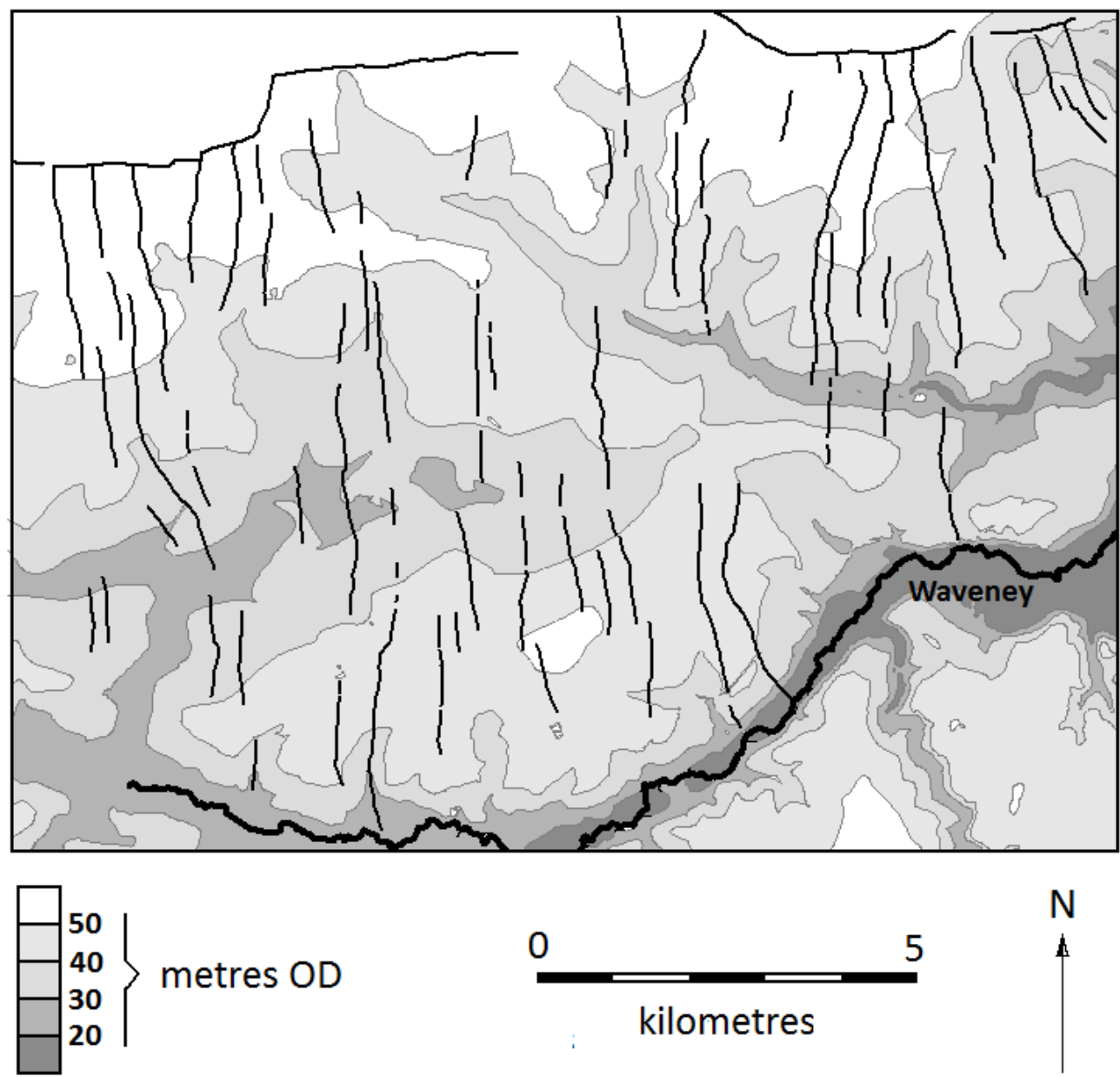

3. The principal elements of the Scole-Dickleburgh landscape are a number of roughly parallel droveways or tracks running out of the Waveney valley, heading for the high ground along the watershed to the north.

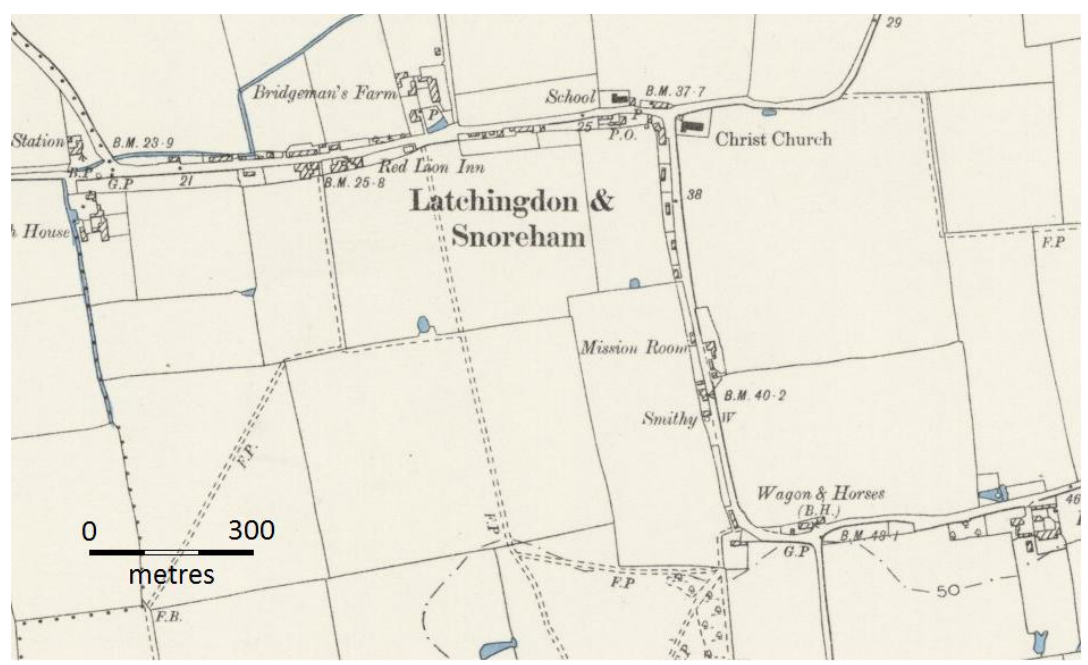

4. Detail of the Dengie field system (as depicted on the Ordnance Survey 1:10,560 map of 1881), showing how the plan of the village of Latchingdon largely comprises partially infilled droveways. 


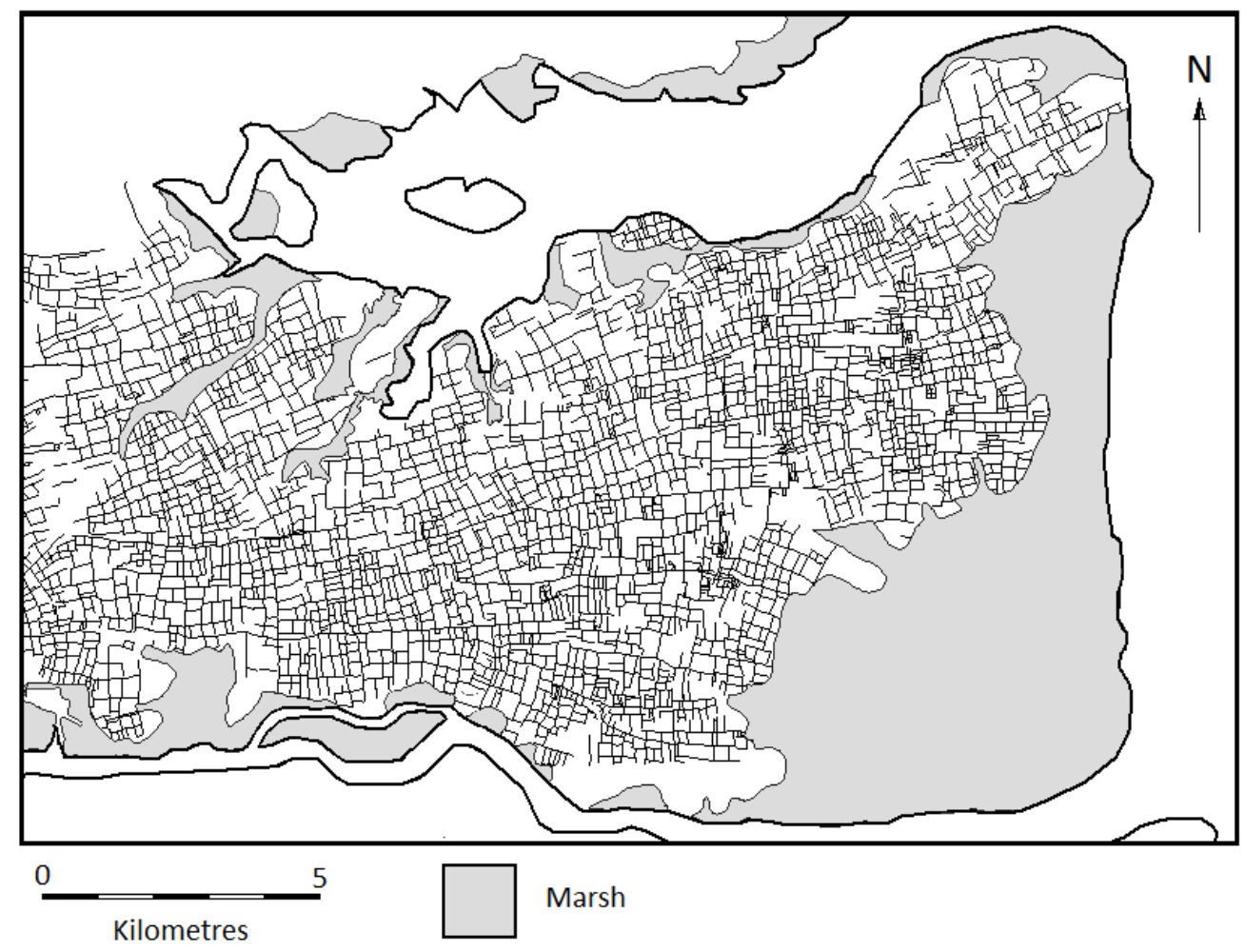

5. The 'planned grid' on the Dengie peninsula (based on the relevant sheets of the Ordnance Survey 1: 10,560 maps surveyed in the 1870s).

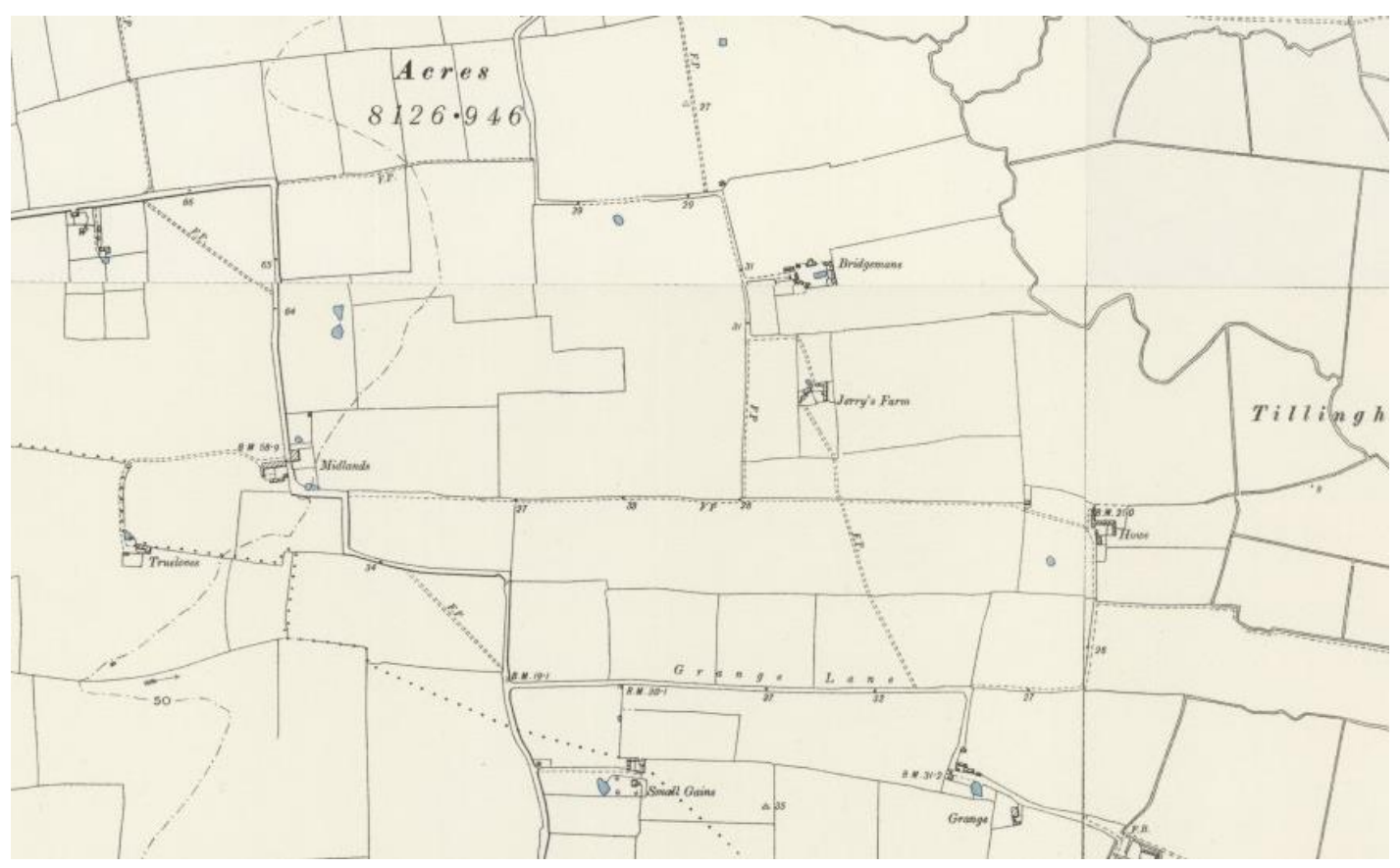

6. Details of the Dengie field system: parallel roads and boundaries approaching the western end of the peninsula, near Tillingham Marshes (as shown on the Ordnance Survey 1:10,560 
map of 1881). Modern roads follow, and leave, the main axes in a manner which suggests that most of the main linear elements in the landscape originated as droves or trackways.

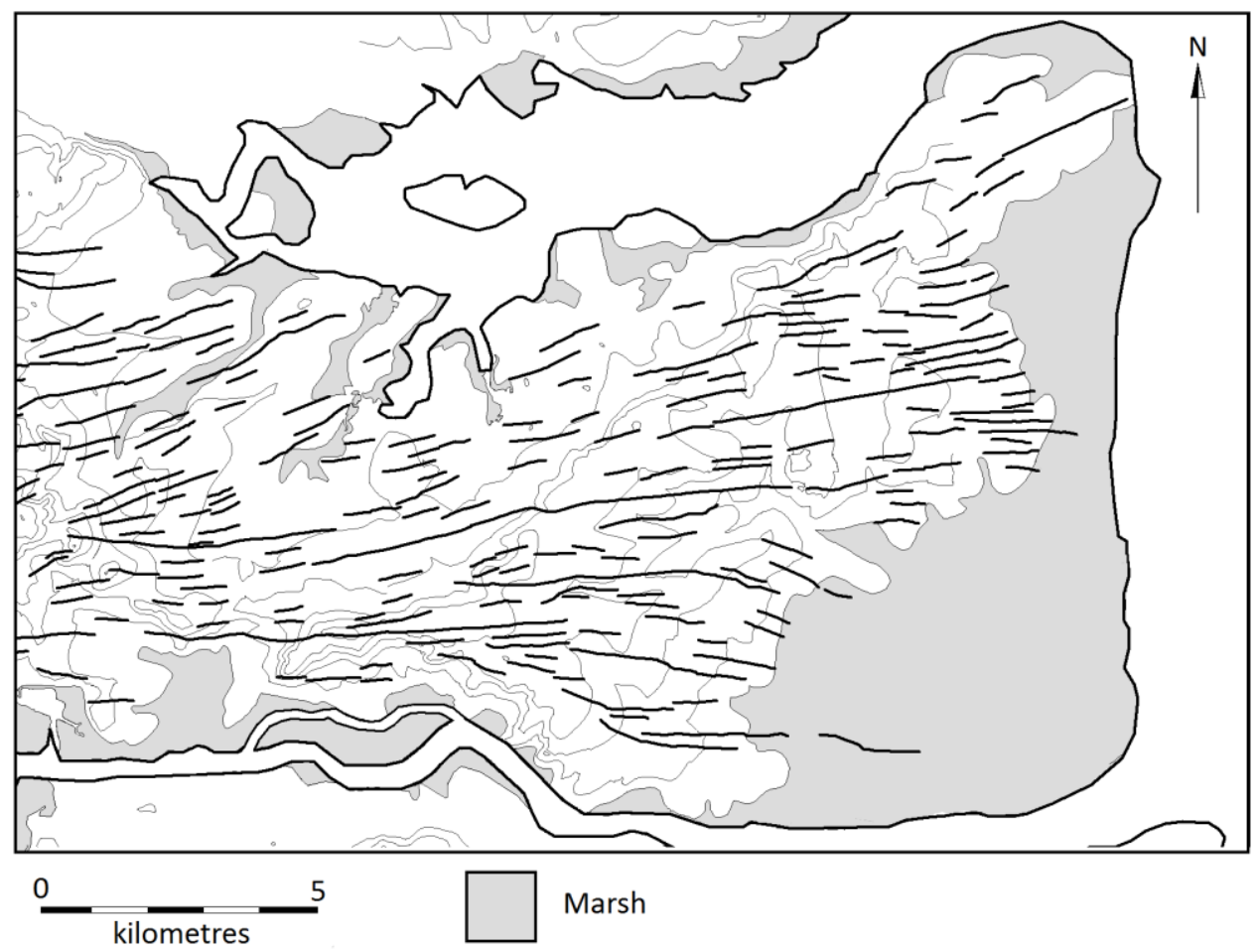

7. The principal east-west elements of the Dengie landscape.

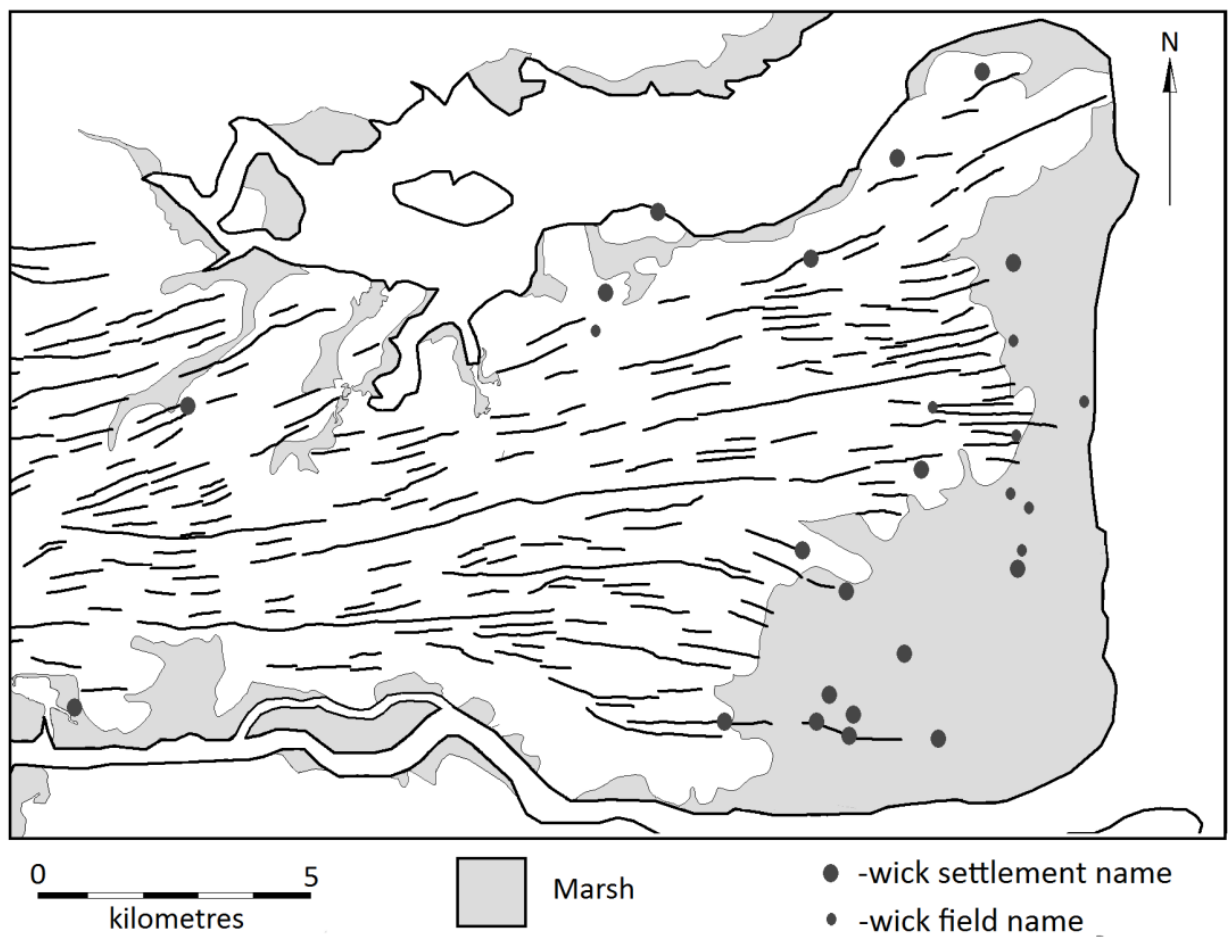

8. The principal east-west elements of the Dengie landscape and the locations of farms and fields with names incorporating the element 'wick'. 


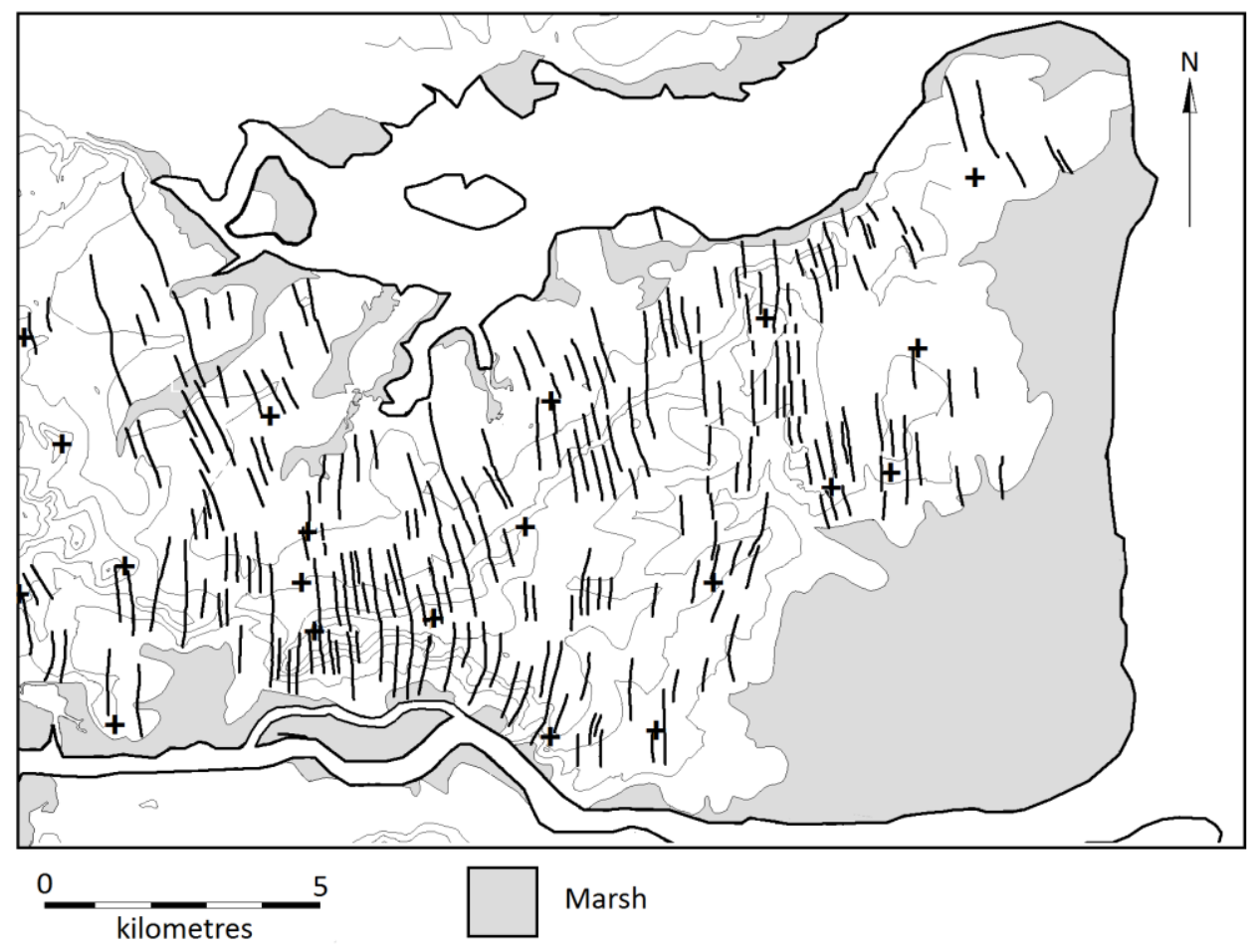

9. The principal north-south elements of the Dengie landscape, and sites of medieval parish churches.

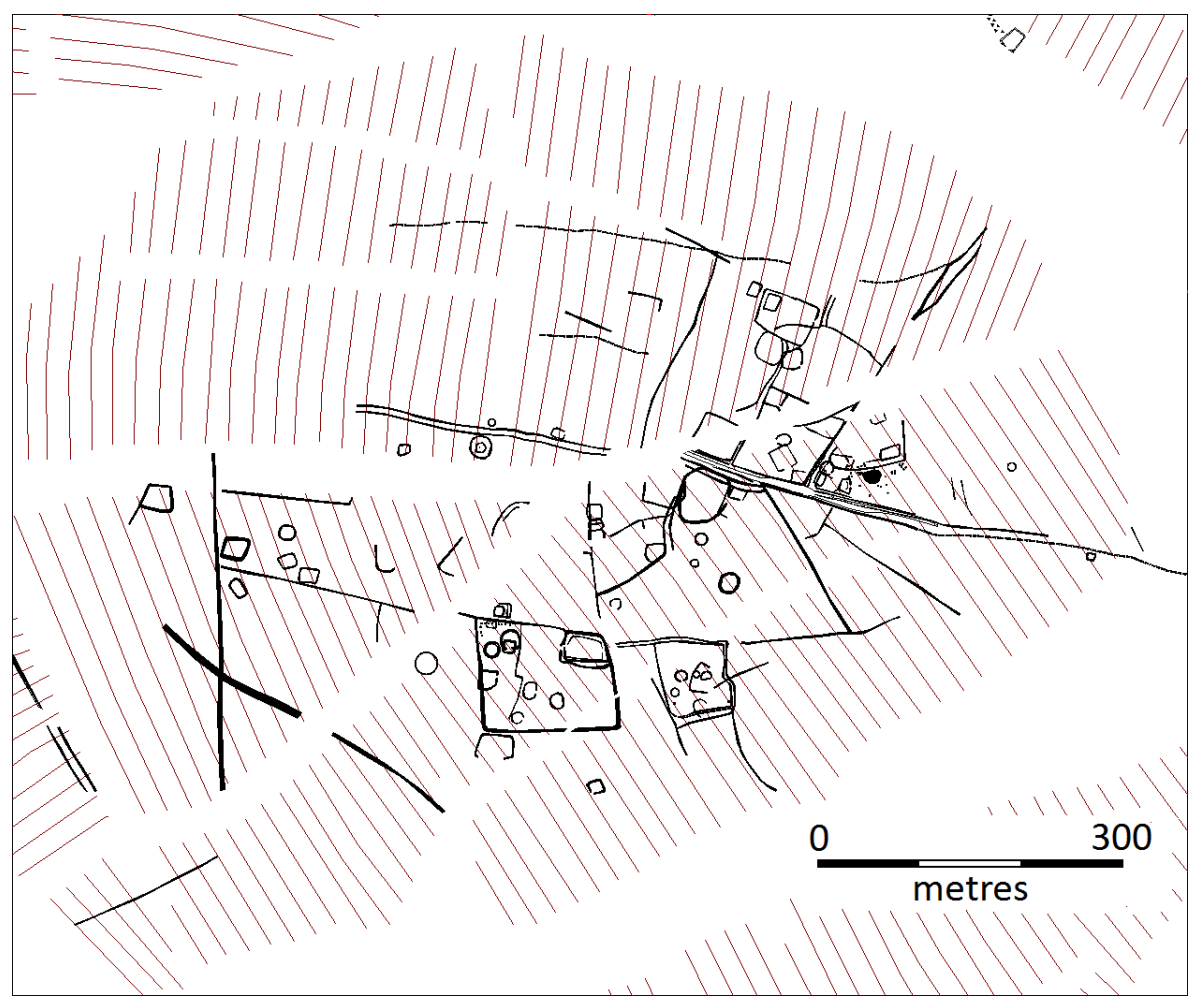

10. Harlestone, Northamptonshire. In most cases, the cropmarks of prehistoric and Roman fields, roads and enclosures in Northamptonshire lie on significantly different alignments to 
the pattern of medieval strips and furlongs reconstructed from archaeological and cartographic evidence (each strip represents four selions in the open fields: see Williamson et al. 2013).

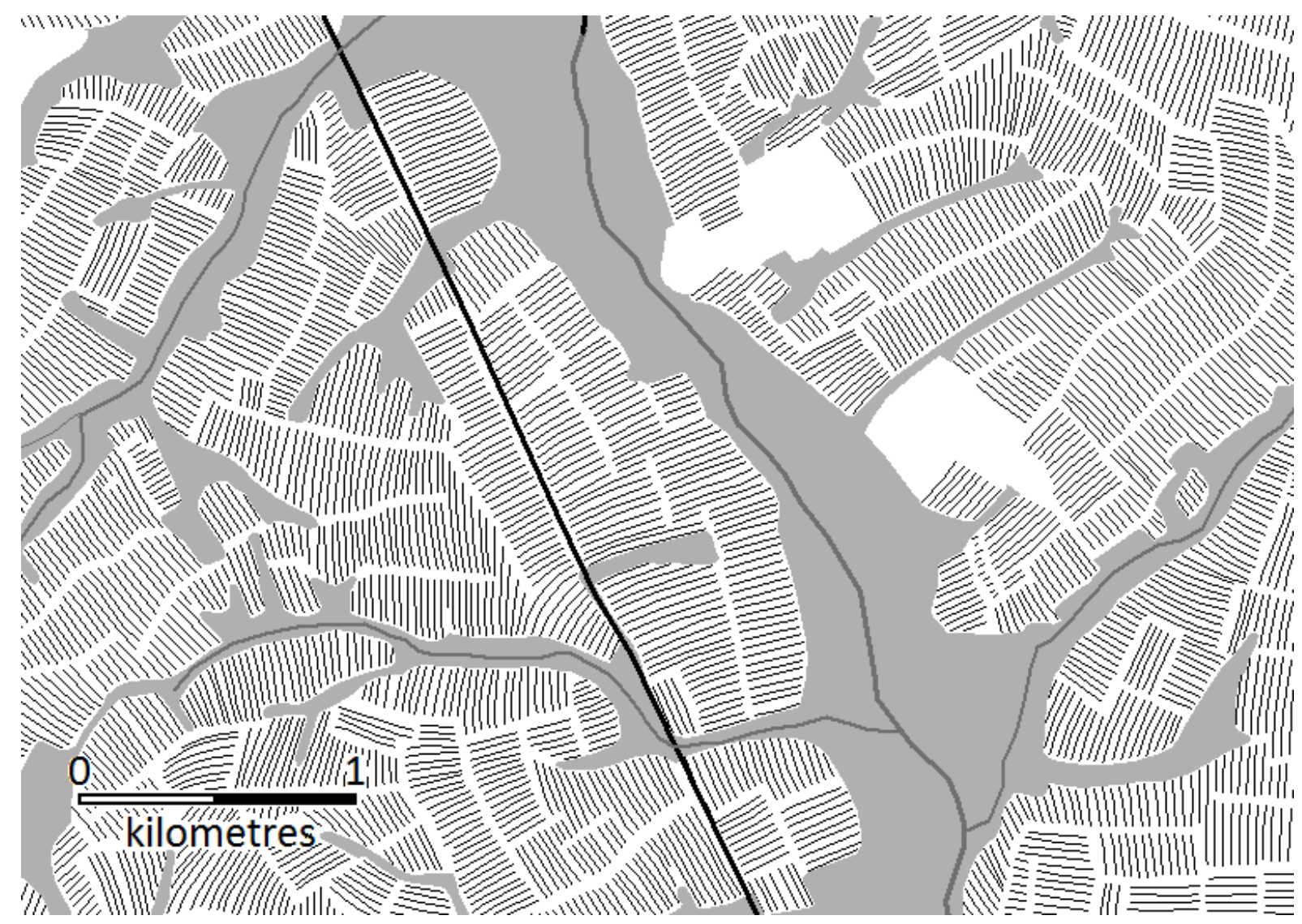

11. The course of Watling Street as it passes through western Northamptonshire (in Brockhall, Norton, Dodford and Muscott); and the pattern of medieval strips and furlongs reconstructed from archaeological and cartographic evidence. Here, as elsewhere in its course through the county, there is little indication that the road has been imposed on earlier patterns of land division. Areas detailed in grey represent meadow and pasture; selions represented as in illustration 10). 